\title{
APLIKASI PERSAMAAN REHBOCK, KINSVATER - CARTER, DAN PERSAMAAN UMUM PADA BANGUNAN UKUR SEGI EMPAT SKALA LABORATORIUM
}

\author{
Suhardi \\ Jurusan Teknik Pertanian, Universitas Jember \\ Email: hardi.ftp@unej.ac.id
}

DOI: http://dx.doi.org/10.29303/jpft.v5i2.1383

\begin{abstract}
The rectangular sharp-crested weir often finds in irrigation open channels. The function of the rectangular sharp-crested weir measures and divides the water flow to be distributed to agricultural lands. The Rehbock equation, the Kinsvater-Carter equation, and the General equation are used to approach the discharge. On a laboratory scale, the measurement of the discharge using a small rectangular sharp-crested weir was used for experiments and simulations. Because of using The Rehbock equation, The Kinsvater-Carter equation, and The General equation for a field discharge measurements, it is necessary to research to find out the accuracy of the Rehbock Equation, the Kinsvater-Carter equation and the General equation in the laboratory scale. The research data included the dimensions of rectangular weirs, the height of the water on the rectangular sharp-crested weir, the width of the channel on the hydraulic bench and the actual discharge. Data collection of the height of water on the rectangular sharp-crested weir and the actual discharge was carried out 5 times the measurements with different discharges. These data were analyzed using the Rehbock equation, the Kinsvater-Carter equation, and the General equation. The discharge of the analysis results was compared with the actual discharge to find out the value of the calibration coefficient. The experimental results show that the Kinsvater-Carter equation and General equation can be applied for discharge measurements on the laboratory scale. The calibration coefficient for the Kinsvater-charter equation was 0.89 and the calibration coefficient for the general equation was 0.94 .
\end{abstract}

Keywords: Rectangular sharp-crested; discharge; calibration coefficient; laboratory

\section{PENDAHULUAN}

Pengukuran debit di lapang terdiri dari pengukuran secara langsung dan pengukuran tidak langsung. Pengukuran debit secara langsung antara lain pengukuran debit menggunakan current meter, pelampung dan penakaran volume air selama waktu tertentu. Sementara itu, pengukuran debit secara tidak langsung adalah pengukuran debit menggunakan bangunan ukur. Bangunun ukur debit biasanya ditempatkan di saluran primer, saluran sekunder maupun saluran tersier. Bangunan ukur debit biasanya diletakkan tegak lurus terhadap arah saluran (Al Shaikhli \& Kadhim, 2018). Bangunan ukur biasanya digunakan untuk menghitung dan menyalurkan debit air sesuai dengan kebutuhan air irigasi. Jenis bangunan ukur bermacam-macam antara lain bangunan ukur ambang tajam segi empat, bangunan ukur ambang tajam trapisium, bangunan ukur ambang tajam segitiga, dan lain-lain. Bangunan ukur ambang tajam segi empat mempunyai luas penampang lebih besar dari bangunan ukur penampang tajam trapisium. Kedua bangunan ukur ini digunakan untuk mengukur debit aliran besar. Sementara bangunan ukur ambang tajam segitiga digunakan untuk mengukur debit aliran kecil dengan akurasi cukup tinggi (Sumirman \& Lasminto, 2013). Masing-masing bangunan ukur dilengkapi dengan persamaan matematika untuk menghitung debit air. Secara umum persamaan matematika dari masing-masing bangunan ukur ini digunakan untuk pengukuran debit pada saluran, baik saluran primer, saluran sekunder maupun saluran tersier.

Pengukuran debit secara tidak langsung menggunakan bangunan ukur ambang tajam segi empat telah banyak digunakan di saluran terbuka (Edijantno et al. 2019)(Soiyuddin et al. 2012). 
Pengukuran debit pada bangunan ukur segi empat adalah dengan mengukur tingi air yang melalui mercu (Ginanjar \& Hariati, 2015). Persamaan matematik yang sering digunakan adalah persamaan Rehbock, persamaan Kinsvater - Carter, dan persamaan Umum dengan persyaratan dan ketentuan yang berbeda. Mengingat ketentuan tentang dimensi bangunan ukur yang tertuang dalam SNI 8137:2015 diperuntukkan pada skala lapangan maka pengukuran debit pada penelitian ini bersifat laboratorium. Dengan demikian pemakaian alat dalam percobaan ini tentunya mempunyai perbedaan karakteristik fisik dengan bangunan yang sebenarnya di lapangan (Pudyono, 2010).

Tujuan dari penelitian ini adalah mengetahui akurasi pengukuran debit skala laboratorium menggunakan persamaan Rehbock, persamaan Kinsvater - Carter, dan persamaan Umum. Manfaat yang diperoleh dari penelitian adalah aplikasi persamaan Rehbock, persamaan Kinsvater Carter, dan persamaan Umum pada kegiatan praktikum pengukuran debit saluran terbuka menggunakan prototipe bangunan ukur ambang tajam segi empat.

\section{METODE PENELITIAN}

Penelitian ini dilaksanakan di Laboratorium Teknik Pengendalian dan Konservasi Lingkungan Jurusan Teknik Pertanian Fakultas Teknologi Pertanian Universitas Jember.

Penelitian ini bersifat eksperimen yang dilakukan di laboratorium. Data-data kuantitatif hasil eksperimen berupa dimensi bangunan ukur, tinggi air di atas mercu, volume air aktual tertampung di bak volumetrik, dan waktu yang diperlukan untuk menampung air di volumetrik. Datadata tersebut dianalisis untuk menjawab permalasahan yang telah disebutkan. Analisis data dilakukuan dengan beberapa tahapan antara lain perhitungan debit aktual, perhitungan debit teoritis, perhitungan kesalahan relatif dan perhitungan koefisien kalibrasi

Peralatan yang digunakan antara lain peralatan kategori 1 berupa stopwatch, penggaris, jangka sorong, prototipe bangunan ukur segi empat dan peralatan kategori 2 berupa 1 unit hydraulic bench. Hydraulic bench ini merupakan peralatan simulasi saluran terbuka yang dilengkapi dengan reservoir, pompa sentrifugal, saluran pembawa dan bak volumetrik. Pompa berfungsi untuk mengalirakan air dari reservoir ke saluran pembawa. Pada ujung saluran terbuka terdapat sekat yang berfungsi sebagai tempat pemasangan prototipe bangunan ukur. Bangunan ukur dapat dibongkar dan dipasang sewaktuwaktu sesuai dengan kebutuhan penelitian. Bagian bawah bangunan ukur terdapat bak volumetrik yang berfungsi mengukur volume aktual air yang tertampung. Secara detail peralatan yang digunakan dalam penelitian ini dapat dilihat pada Gambar 1 . Sementara bahan yang digunakan dalam penelitian ini adalah bahan umum berupa lilin malam dan air.

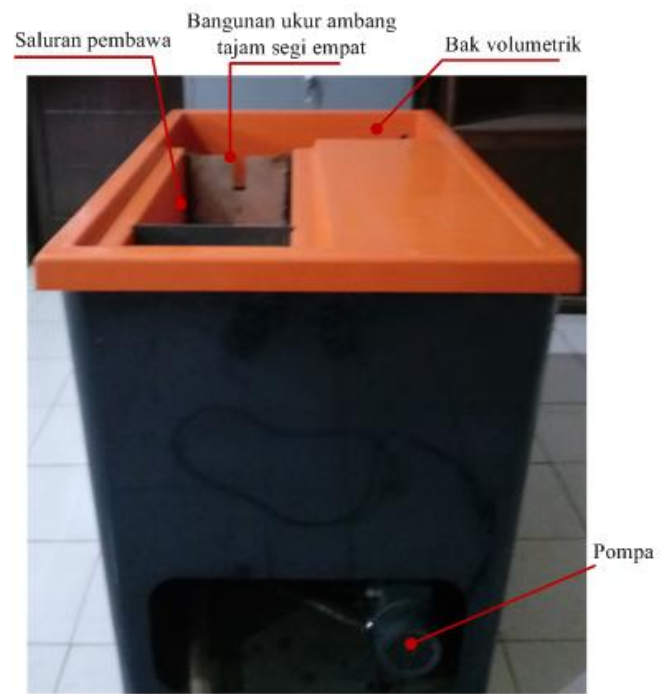

Gambar 1. Peralatan hydraulic bench Beberapa tahapan penelitian yang dilakukan antara lain sebagai berikut ini.

1. Pengukuran dimensi bagunan ukur meliputi pengukuran lebar ambang tajam dan tinggi mercu diatas dasar saluran. 
Sementara pengukuran lebar saluran pembawa diukur mulai dari tepi dinding saluran ke dinding saluran pembawa sisi lainnya seperti yang tampak pada Gambar 2 berikut ini.

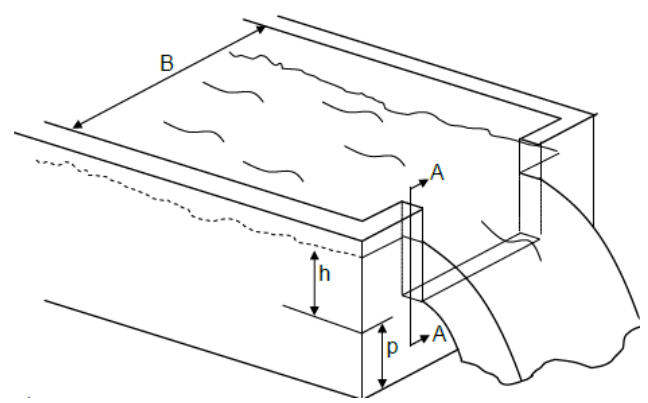

Keterangan: B adalah lebar saluran pembawa $\mathrm{p}$ adalah tinggi mercu dari dasar saluran

$\mathrm{h}$ adalah tinggi air dari mercu

Gambar 2. Profil saluran dan bangunan ukur segi empat (Sumber: SNI 8137:2015)

2. Pengukuran tinggi air di atas mercu dilakukun setelah air dipompa dari reservoir ke saluran pembawa, kemudian air tersebut dialirkan mercu bangunan ukur. Pengukuran tinggi air di atas mercu menggunakan alat ukur tinggi air seperti tampak pada Gambar 3 berikut ini.

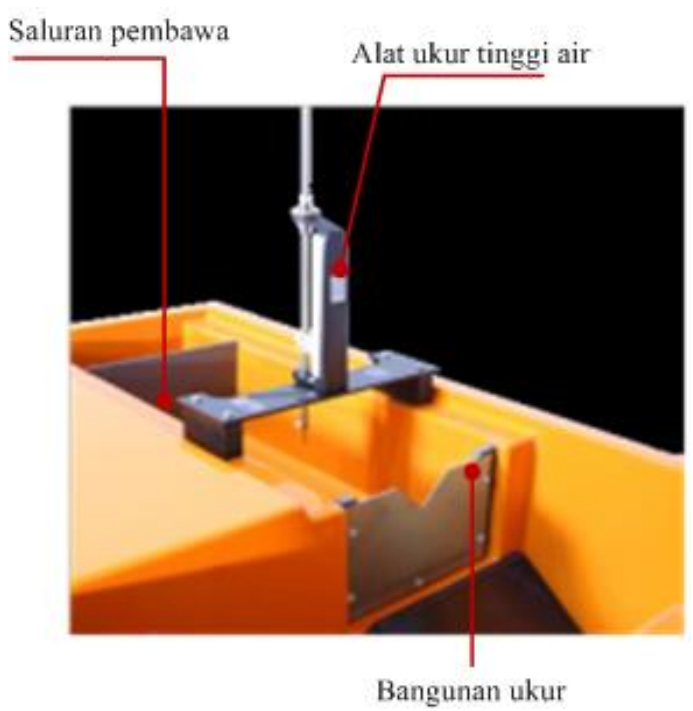

Gambar 3. Saluran pembawa, bangunan ukur, dan pengukur tinggi air (sumber: Armfield, 2018)

3. Pengukuran debit aktual
Pengukuran debit aktual dilakukan dengan menampung air yang melewati mercu, kemudian diukur volume dan waktu yang diperlukan untuk menampung air tersebut (Waspodo, 2017). Debit aktual dapat dihitung dengan persamaan berikut.

$Q=\frac{V}{T}$

$\mathrm{Q}$ adalah debit ( $\mathrm{m}^{3} /$ detik), $\mathrm{V}$ adalah volume air tertampung $\left(\mathrm{m}^{3}\right)$, dan T adalah waktu yang diperlukan untuk mengukur volume air (detik).

4. Perhitungan debit menggunakan bangunan ukur ambang tajam segi empat dapat dilakukan dengan persamaan (Badan Standardisasi Nasional, 2015):

\section{a. Persamaan Rehbock}

$Q=\frac{2}{3} \sqrt{2 g}\left(0,602+0,0822 \frac{h}{p}\right) b(h+0,00125)^{2 / 2}$

$\mathrm{Q}$ adalah debit ( $\mathrm{m}^{3} /$ detik), g percepatan gravitasi $\left(\mathrm{m} / \mathrm{det}^{2}\right)$, dan $\mathrm{h}$ adalah tinggi muka air (m), b adalah lebar mercu (m) dan $\mathrm{p}$ adalah tinggi mercu dari dasar saluran (m).

b. Persamaan Kinsvater-Carter

$Q=\left[\frac{2}{3}\right] \sqrt{2 g} \cdot C_{d} \cdot b_{a} \cdot\left(H_{e f}\right)^{3 / 2}$

$\mathrm{Q}$ adalah debit ( $\mathrm{m}^{3} /$ detik), g percepatan gravitasi $\left(\mathrm{m} / \mathrm{det}^{2}\right)$, dan $\mathrm{H}_{\mathrm{ef}}$ adalah tinggi muka air efektif (m), ba adalah panjang bentang mercu ambang efektif (m) dan Cd adalah koefisien debit.

$\mathrm{Hef}=\mathrm{h}+\delta \mathrm{H}$

$\delta \mathrm{H}$ merupakan kondisi terkait kekentalan fluida dan tegangan permukaan. Pada suhu air normal, $4-20^{\circ} \mathrm{C}, \delta \mathrm{H}$ sebesar $0,001 \mathrm{~m}$. 
$\mathrm{ba}=\mathrm{b}+\delta \mathrm{b}$

b adalah faktor koreksi yang merupakan fungsi $\frac{b}{\mathrm{~B}}$, untuk kondisi suhu air normal dan harga $\delta$ b dapat ditentukan berdasarkan Gambar 4.

Nilai koefisien debit, $\mathrm{Cd}$ dapat ditentukan berdasarkan harga $\frac{h}{\mathrm{P}}, \mathrm{h}$ seperti ditunjukkan pada Gambar 5.

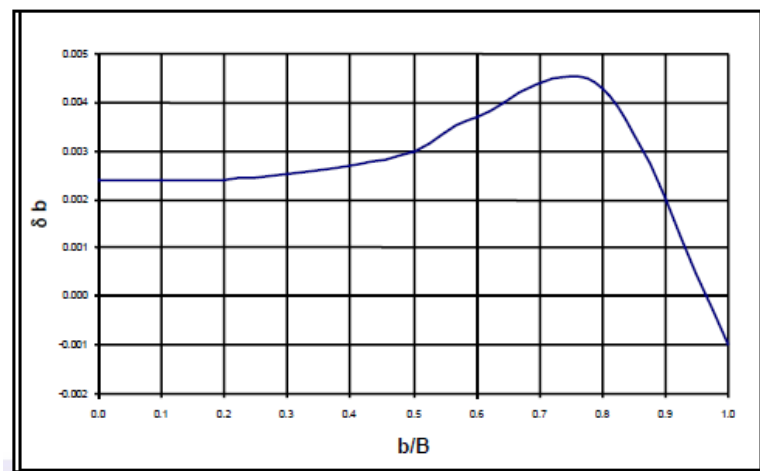

Gambar 4. Penentuan harga $\delta$ b (Sumber: SNI 8137:2015).

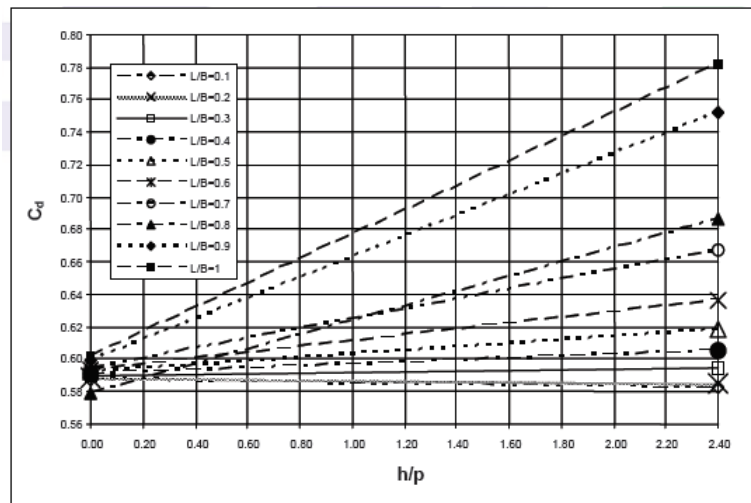

Gambar 5. Penentuan harga Cd (Sumber: SNI $8137: 2015)$

c. Persamaan Umum (Anggrahini, 2005)

$Q=1,71 m \cdot b \cdot h^{3 / 2}$

$\mathrm{Q}$ adalah debit ( $\mathrm{m}^{3} /$ detik), m koefisien debit $(0,9-1,30)$, dan $h$ adalah tinggi muka air (m), b adalah lebar mercu (m)

5. Kalibrasi bangunan ukur dan kesalahan relatif.

Kalibrasi bangunan ukur ambang tajam segi empat dapat dilakukan apabila kesalaan relatif lebih besar dari 5\% sehingga diperlukan penyesuaian debit dengan mencari koefisien kalibrasi (K). Kesalahan relatif dapat dihitung dengan persamaan berikut (Hidayah and Dermawan, 2015).

$K r(\%) \frac{|Q a c t-Q t|}{Q a c t} \times 100 \%$

$\mathrm{Kr}$ adalah kesalahan relatif, Qact ( $\mathrm{m}^{3} /$ detik), adalah debit aktual, dan Qt $\left(\mathrm{m}^{3} /\right.$ detik$)$, adalah debit teori.

Sementara itu kalibrasi bangunan ukur dapat dihitung dengan persamaan berikut.

$K=\frac{Q a c t}{Q t}$

$\mathrm{K}$ adalah koefisien kalibrasi, Qact adalah debit aktual, dan Qt debit hasil perhitungan menggunakan persamaan bangunan ukur segi empat.

\section{HASIL DAN PEMBAHASAN}

Berdasarkan beberapa tahapan penelitian yang telah dilakukan antara lain perhitungan debit aktual dan perhitungan debit air menggunakan persamaan bangunan ukur segi empat.

Debit aktual dihasilkan dari pengukuran volume air aktual yang melewati mercu prototipe bangunan ukur dan tertampung di bak volumetrik. Waktu yang diperlukan untuk menampung volume air dicatat sehingga dihasilkan data volume air terukur dan waktu pengukuran. Dengan demikian, debit aktual dapat dihitung dengan persamaan 1. Hasil perhitungan debit aktual dapat dilihat pada Tabel 1.

Pada percobaan pengkuran debit aktual ini dilakukan dengan cara mengukur volume air dan waktu pada pengaturan debit yang berbeda. Tabel 1 menunjukkan 5 kali pengukuran volume air melalui mercu dan pengukuran waktu selama menampung air. 
Volume air yang tertampung ditetapkan sebanyak $0,005 \mathrm{~m}^{3}$. Mengingat percobaan dilakukan pada debit yang berbeda-beda maka waktu yang diperlukan untuk menampung air tersebut berbeda pula. Selanjutnya, berdasarkan data volume dan waktu ini dihasilkan debit aktual.

Tabel 1. Debit aktual yang melewati mercu prototipe bangunan ukur segi empat

\begin{tabular}{cccc}
\hline No & $\begin{array}{c}\text { Volume } \\
\text { terukut } \\
\left(\mathrm{m}^{3}\right)\end{array}$ & $\begin{array}{c}\text { Waktu } \\
\text { pengukuran } \\
(\text { detik })\end{array}$ & $\begin{array}{c}\text { Debit aktual } \\
\text { melalui mercu } \\
\left(\mathrm{m}^{3} / \text { detik }\right)\end{array}$ \\
\hline 1 & 0,005 & 6,50 & 0,00077 \\
\hline 2 & 0,005 & 7,43 & 0,00067 \\
\hline 3 & 0,005 & 7,62 & 0,00066 \\
\hline 4 & 0,005 & 8,45 & 0,00059 \\
\hline 5 & 0,005 & 10,27 & 0,00049 \\
\hline
\end{tabular}

Perhitungan debit air melalui mercu prototipe bangunan ukur segi empat dilakukan dengan beberapa tahapan antara lain pengukuran dimensi saluran dan pengukuran tinggi air di atas mercu. Pengukuran dimensi saluran pembawa dilakukan dengan mengukur batas antara penampang basah dari kedua sisi saluran pembawa. Sementara pengukuran dimensi prototipe banguan ukur meliputi lebar mercu dan tinggi mercu dari dasar saluran. Pengukuran tinggi air di atas mercu $(\mathrm{H})$ dilakukan dengan menempatkan alat ukur tinggi air di atas mercu prototipe bangunan ukur, selanjutnya menentukan ketinggian datum dari mercu tersebut. Saat debit air dialirkan menuju ke saluran pembawa dan melewati mercu, pengukur tinggi air ditempatkan di hulu bangunan ukur sejauh 4 kali tinggi muka air $(\mathrm{H})$. Mengingat saluran pembawa pada alat hydraulic bench cukup pendek sehingga muka air bergolak, maka pengukuran tinggi air dilakukan sebanyak 3 kali yaitu masing-masing satu kali pengukuran tinggi air pada bagian saluran hulu, tengah dan hilir. Hal ini dilakukan untuk meningkatkan akurasi pengukuran tinggi muka air. Selanjutnya tinggi air hasil pengukuran dirata-rata. Hasil pengukuran tinggi air di atas mercu dapat dilihat pada Tabel 2 berikut ini.

Tabel 2. Pengukuran tinggi air di atas mercu

\begin{tabular}{ccccc}
\hline \multirow{2}{*}{ No } & \multicolumn{4}{c}{ Tinggi air $(\mathrm{m})$} \\
\cline { 2 - 5 } & Hulu & Tengah & Hilir & Rata-rata \\
\hline 1 & 0,0487 & 0,0498 & 0,0480 & 0,0488 \\
\hline 2 & 0,0440 & 0,0450 & 0,0460 & 0,0450 \\
\hline 3 & 0,0433 & 0,0436 & 0,0440 & 0,0436 \\
\hline 4 & 0,041 & 0,0414 & 0,0418 & 0,0414 \\
\hline 5 & 0,0357 & 0,036 & 0,0373 & 0,0363 \\
\hline
\end{tabular}

Tinggi air di atas mercu pada Tabel 2 tersebut merupakan data tinggi air di atas mercu pada 5 kali pengukuran debit yang berbeda. Data tinggi air di atas mercu ini selanjutnya akan digunakan untuk menghitung debit aliran air melalui prototipe bangunan ukur segi empat.

Perhitungan debit aliran air pada bangunan ukur ambang tajam segi empat (Rehbock) menggunakan persamaan 2. Perhitungan debit Kinsvater - Carter menggunakan persamaan 3 sampai dengan persamaan 5. Sementara Persamaan 6 merupakan persamaan untuk menghitung debit air pada bangunan ukur segi empat metode Anggraini. Untuk menghitung nilai $\delta$ b pada persamaan 5 didasarkan pada perbandingan lebar mercu (b) dan lebar saluran pembawa (B). Pada Gambar 4 menunjukkan bahwa hasil $\mathrm{b} / \mathrm{B}$ ditarik garis vertikal sampai menyentuk grafik melengkung, selanjutnya ditarik garis horisontal ke sebelah kiri untuk menunjukkan nilai $\delta b$. Sementara untuk mencari nilai Cd pada Gambar 5 dilakukan dengan cara menghitung perbandingan antara $\mathrm{h}$ dan $\mathrm{p}(\mathrm{h} / \mathrm{p})$ terlebih dahulu, kemudian dari nilai $\mathrm{h} / \mathrm{p}$ ditarik garis vertikal sampai menyentuk grafik. Setelah menyentuk salah satu grafik kemudian ditarik ke sebelah kiri secara horisantal untuk menentukan nilai koefisien debit $(\mathrm{Cd})$. Terdapat 10 grafik yang menggambarkan nilai perbandingan mercu (b) dan lebar saluran pembawa (B). Dimana nilai b/B 
secara berurutan dari grafik paling atas adalah 0,1 sampai $1 . \quad$ Apabila nilai perbandingan antara $\mathrm{b} / \mathrm{B}$ menghasilkan 0,1 maka penarikan garis vertikal dari sumbu $\mathrm{x}$ $(\mathrm{h} / \mathrm{p})$ harus menyentuk grafik 0,1 kemudian dilanjutkan dengan menarik garis horisontal ke kiri. Perhitungan debit berdasarkan persamaan Rehbock, Kinsvater-Carter, dan persamaan umum dapat dilihat pada Tabel 3 sampai dengan Tabel 5 berikut ini.

Tabel 3. Perhitungan debit menggunakan persamaan Rehboock.

\begin{tabular}{ccccc}
\hline No & $\begin{array}{c}\mathrm{h} \\
(\mathrm{m})\end{array}$ & $\begin{array}{c}\mathrm{p} \\
(\mathrm{m})\end{array}$ & $\begin{array}{c}\mathrm{b} \\
(\mathrm{m})\end{array}$ & $\begin{array}{c}\text { Debit }(\mathrm{Q}) \\
\left(\mathrm{m}^{3} / \mathrm{detik}\right)\end{array}$ \\
\hline 1 & 0,0488 & 0,077 & 0,030 & 0,00192 \\
\hline 2 & 0,0450 & 0,077 & 0,030 & 0,00164 \\
\hline 3 & 0,0436 & 0,077 & 0,030 & 0,00154 \\
\hline 4 & 0,0414 & 0,077 & 0,030 & 0,00139 \\
\hline 5 & 0,0363 & 0,077 & 0,030 & 0,00107 \\
\hline
\end{tabular}

Tabel 4. Perhitungan debit menggunakan persamaan Kinsvater - Carter

\begin{tabular}{ccccc}
\hline No & $\begin{array}{c}\mathrm{H}_{\mathrm{ef}} \\
(\mathrm{m})\end{array}$ & $\mathrm{Cd}$ & $\begin{array}{c}\text { ba } \\
(\mathrm{m})\end{array}$ & $\begin{array}{c}\text { Debit }(\mathrm{Q}) \\
\left(\mathrm{m}^{3} / \mathrm{detik}\right)\end{array}$ \\
\hline 1 & 0,0498 & 0,650 & 0,032 & 0,00068 \\
\hline 2 & 0,0460 & 0,646 & 0,032 & 0,00060 \\
\hline 3 & 0,0446 & 0,646 & 0,032 & 0,00058 \\
\hline 4 & 0,0424 & 0,643 & 0,032 & 0,00053 \\
\hline 5 & 0,0373 & 0,635 & 0,032 & 0,00043 \\
\hline
\end{tabular}

Tabel 5. Perhitungan debit menggunakan persamaan umum

\begin{tabular}{ccccc}
\hline No & $\begin{array}{c}\mathrm{h} \\
(\mathrm{m})\end{array}$ & $\mathrm{m}$ & $\begin{array}{c}\mathrm{b} \\
(\mathrm{m})\end{array}$ & $\begin{array}{c}\text { Debit }(\mathrm{Q}) \\
\left(\mathrm{m}^{3} / \text { detik }\right)\end{array}$ \\
\hline 1 & 0,0488 & 1,30 & 0,030 & 0,00072 \\
\hline 2 & 0,0450 & 1,30 & 0,030 & 0,00064 \\
\hline 3 & 0,0436 & 1,30 & 0,030 & 0,00061 \\
\hline 4 & 0,0414 & 1,30 & 0,030 & 0,00056 \\
\hline 5 & 0,0363 & 1,30 & 0,030 & 0,00046 \\
\hline
\end{tabular}

Pada Tabel 3 sampai dengan Tabel 5 menunjukkan bahwa perhitungan debit menggunakan persamaan Rehbock, Kinsvater - Carter, dan persamaan umum mempunyai tingkat akurasi yang berbeda terhadap debit aktual (kontrol). Perhitungan debit menggunakan persamaan Rehbock lebih kecil bila dibandingan dengan persamaan Kinsvater - Carter, dan persamaan umum. Perhitungan debit dengan persamaan Kinsvater - Carter dan persamaan umum menunjukkan hasil lebih baik, hal ini ditunjukkan bahwa hasil perhitugan debit dengan persamaan tersebut mendekati debit kontrol (Tabel 1).

Untuk mengetahui tingkat akurasi dari persamaan - persamaan tersebut dalam menghitung debit air pada bangunan ukur segi empat skala laboratorium maka dilakukan perhitungan kesalahan ralatif.

Hasil perhitungan kesalahan relatif dari persamaan Rehbock, KinsvaterCarter, dan persamaan umum disajikan pada Tabel 6 berikut.

Tabel 6. Perhitungan kesalahan relatif

\begin{tabular}{|c|c|c|c|}
\hline \multirow[t]{3}{*}{ No } & \multirow{2}{*}{\multicolumn{3}{|c|}{$\begin{array}{c}\text { Kesalahan relatif terhadap debit aktual } \\
\text { (kontrol) }(\%)\end{array}$}} \\
\hline & & & \\
\hline & Rehboock & $\begin{array}{c}\text { Kinsvater- } \\
\text { Cater }\end{array}$ & Umum \\
\hline 1 & 60,02 & 12,64 & 6,89 \\
\hline 2 & 58,90 & 11,80 & 5,71 \\
\hline 3 & 57,41 & 14,05 & 7,95 \\
\hline 4 & 57,41 & 11,60 & 5,33 \\
\hline 5 & 54,68 & 12,54 & 5,41 \\
\hline Rata2 & 57,69 & 12,52 & 6,26 \\
\hline
\end{tabular}

Tabel 6 menunjukkan bahwa ketiga persamaan debit untuk bangunan ukur segi empat mempunyai tingkat kesalahan relatif rata-rata lebih besar dari 5\%. Namun untuk persamaan umum masih dibwah $10 \%$. Hal ini menunjukkan bahwa persamaan umum dapat diterapkan untuk pengukuran debit bangunan ukur skala laboratorium. Hal ini sejalan dengan pendapat Pudyono (2010) yang menyatakan bahwa kesalahan relatif dibawah $10 \%$ dapat dipertanggungjawabkan kebenarannya. Namun demikian persamaan dengan kesalahan relatif di atas 5\% tidak dapat secara langsung digunakan untuk menghitung debit pada prototipe bangunan ukur skala laboratorium dengan dimensi lebar mercu (b) $30 \mathrm{~cm}, \mathrm{p}=7,7 \mathrm{~cm}$. Hal ini juga sejalan dengan pendapat Hidayah and Dermawan (2015) bahwa kesalahan relatif kurang dari $10 \%$ perlu dilakkukan perhitungan koefisien kalibrasi. Oleh karena 
itu, koefisien kalibrasi dari ketiga persamaan tersebut perlu dihitung seperti disajikan dalam Tabel 7.

Tabel 7. Perhitungan koefisien kalibrasi

\begin{tabular}{cccc}
\hline No & \multicolumn{3}{c}{ Koefisien kalibrasi untuk persamaan } \\
& \multicolumn{3}{c}{ debit } \\
\cline { 2 - 4 } & Rehboock & $\begin{array}{c}\text { Kinsvater- } \\
\text { Cater }\end{array}$ & Umum \\
\hline 1 & 2,76 & 0,89 & 0,94 \\
\hline 2 & 2,68 & 0,89 & 0,95 \\
\hline 3 & 2,59 & 0,88 & 0,93 \\
\hline 4 & 2,60 & 0,90 & 0,95 \\
\hline 5 & 2,45 & 0,89 & 0,95 \\
\hline Rata2 & 2,61 & 0,89 & 0,94 \\
\hline
\end{tabular}

Tabel 7 menunjukkan bahwa ratarata koefisien kalibrasi untuk persamaan Kinsvater- Carter dan persamaan umum mempunyai nilai koefisien kalibrasi 0,89 dan 0,94. Hal ini menunjukkan bahwa kedua persamaan tersebut mempunyai tingkat akurasi tinggi dalam pengukuran debit menggunakan prototipe bangunan ukur skala laboratorium. Namun, untuk persamaan Rehbock sebaiknya tidak digunakan untuk menghitung debit bangunan ukur segi empat skala laboratorium karena tidak akurat dengan koefisien kalibrasi rata-rata 2,61. Hal ini sejajar dengan pendapat Hendriyanto, Purwanto and Setiawan (2019) yang menyatakan bahwa persamaan yang digunakan dalam model dengan koefisien kalibrasi lebih besar 0,80 layak dan dapat digunakan.

\section{PENUTUP}

Berdasarkan hasil pembahasan dapat dikemukakan kesimpulan bahwa pengukuran debit pada bangunan ukur ambang tajam segi empat skala laboratorium menggunakan persamaan Kinsvater-Carter dan persamaan umum sangat akurat, sehingga kedua persamaan tersebut dapat digunakan dalam percobaan skala laboratorium dengan memasukkan koefisien kalibrasi (K) pada masing-masing persamaan. Koefisien kalibrasi (K) untuk persamaan Kinsvater- Carter adalah 0,89 dan 0,94 pada persamaan umum.

\section{UCAPAN TERIMAKASIH}

Terimakasih kepada Ketua Lab TPKL Jurusan Teknik Pertanian yang telah memberikan fasilitas dalam pengambilan data percobaan pengukuran debit di laboratorium.

\section{REFERENSI}

Anggrahini. 2005. Hidrolika Saluran Terbuka. Edited by Devita. Surabaya: Srikandi.

Armfield. 2018. Engineering Teaching and Research Catalogue. Issue-1. England: Armfield Agents. armfieldonline.com > transfer > doc > Armfield_Catalogue-2018_Issue1Live. diakses $\operatorname{tgl} 8$ Agustus 2019

Badan Standardisasi Nasional. 2015. Pengukuran Debit pada Saluran Terbuka Menggunakan Bangunan Ukur Tipe Pelimpah Atas. Jakarta: BSNI.

Edijantno., Lasminto,U., Andeik, M., Ranti, Y., \& Sumirman, E. 2019. Uji kinerja alat ukur ambang tajam berpenampang majemuk. Pertemuan Ilmiah Tahunan HATHI, 1-11.

Ginanjar, B., \& Hariati, F. 2015. Analisis Koefisien Debit Model Alat Ukur Celah Segiempat Di Laboratorium Hidrolika Teknik Sipil Universitas Ibn Khaldun Bogor Bagus, Jurnal Rekayasa Sipil, 4(2), 18-24.

Hendriyanto, H. S., Purwanto, M.Y.J., \& Setiawan, Y. 2019. Penggunaan Tank Model Untuk Mempelajari Tindakan Konservasi Air dan Hubungannya Dengan Debit Sungai di Sub Das Ciliwung Hulu-Ciliwung. Jurnal Keteknikan Pertanian, 7(1), $1-8$.

Hidayah, S., Suhardjono., \& Dermawan, V. 2015. Uji Proporsionalitas Debit Bangunan Bagi Tipe Numbak, Jurnal Irigasi, 10(2), 69-82. 
Pudyono. 2010. Pengaruh Pemasangan Bangunan Peninggi Muka Air (Subweir) Terhadap Gerusan Yang Terjadi di Hilir Bendung, Jurnal Rekayasa Sipil, 4(2), 99-110.

Al Shaikhli, H. I. \& Kadhim, K. N. 2018. Development an equations for flow over weirs using MNLR And CFD simulation approaches, International Journal of Civil Engineering and Technology, 9(3), 70-79.

Soiyuddin, H. A., Muqorrobin, M., Rahmadani, D., Tusi, A., \& Setiawan, B.I. 2012. Pintu Sorong Tonjol Berbahan Fiberglass Sebagai Inovasi Alat Ukur Debit Dalam Operasi Irigasi, Jurnal Sumber Daya Air, 8(1), 27-38.

Sumirman, E. \& Lasminto, U. 2013. Studi Perbandingan Aliran Alat Ukur Debit Ambang Tipis Penampang Segi Tiga dengan Penampang Majemuk. Prosiding Seminar Nasional Aplikasi Teknologi Prasarana Wilayah (ATPW), 1-18.

Waspodo. 2017. Analisa Head Loss Sistem Jaringan Pipa Pada Sambungan Pipa Kombinasi Diameter Berbeda. Jurnal Suara Teknik Fakultas Teknik, 8(1), 1-12. 